\title{
FAKTOR-FAKTOR YANG MEMPENGARUHI KESIAPAN MENJADI GURU PADA MAHASISWA JURUSAN PENDIDIKAN EKONOMI ANGKATAN 2014 UNIVERSITAS PENDIDIKAN GANESHA
}

\author{
I Made Adi Mahardika1 ${ }^{1}$, Lulup Endah Tripalupi², I Wayan Suwendra ${ }^{3}$ \\ Jurusan Pendidikan Ekonomi, Fakultas Ekonomi \\ Universitas Pendidikan Ganesha Singaraja, \\ Indonesia
}
e-mail: adi.mahardika92@gmail.com, endah.tripalupi@undiksha.ac.id, yc9eda@yahoo.co.id

\begin{abstract}
Abstrak
Penelitian ini bertujuan untuk mengetahui faktor-faktor yang mempengaruhi dan faktor yang paling dominan mempengaruhi kesiapan menjadi guru pada mahasiswa di Jurusan Pendidikan Ekonomi angkatan 2014 Universitas Pendidikan Ganesha (Undiksha). Jenis penelitian ini adalah penelitian kuantitatif. Populasi dalam penelitian ini adalah mahasiswa Jurusan Pendidikan Ekonomi angkatan 2014 yang telah mengikuti tes intelegensi berjumlah 40 mahasiswa. Metode pengumpulan data yang digunakan adalah dokumentasi dan kuesioner. Data dianalisis menggunakan analisis faktor dengan program SPSS 16.0 for windows. Hasil penelitian menunjukkan bahwa terdapat delapan faktor yang mempengaruhi kesiapan menjadi guru pada mahasiswa di Jurusan Pendidikan Ekonomi angkatan 2014 Undiksha, yaitu faktor keadaan jasmani dengan nilai variance sebesar $36,538 \%$, faktor pendidikan sekolah dengan nilai variance sebesar $21,209 \%$, faktor minat dengan nilai variance sebesar $14,097 \%$, faktor nilai-nilai kehidupan dengan nilai variance sebesar $7,981 \%$, faktor sifat-sifat dengan nilai variance sebesar $6,909 \%$, faktor pergaulan teman sebaya dengan variance sebesar $5,805 \%$, faktor masyarakat dengan variance sebesar $4,751 \%$, dan faktor pengetahuan dengan variance sebesar $2,710 \%$. Faktor keadaan jasmani menjadi faktor yang paling dominan, karena memiliki nilai varimax rotation sebesar $36,538 \%$, artinya total nilai varimax rotation dari faktor keadaan jasmani mampu menjelaskan kesiapan menjadi guru sebesar $36,538 \%$.
\end{abstract}

Kata kunci: Kesiapan Menjadi Guru, Mahasiswa

\begin{abstract}
This study aimed at discovering the factors influencing and the dominant factor the readiness of being teacher in Economic Education Department batch 2014, Universitas Pendidikan Ganesha (Undiksha). This study was a quantitative study. The population of this study were 40 students who have taken intelligence tests in Economic Education Department batch 2014. The data were collected through documentation and questionnaire. The data were analyzed using factor analysis in SPSS 16.0 for windows. The result of the study shows that there are 8 factors influencing the readiness of being teacher in Economic Education Department batch 2014, Undiksha namely, physical factor with variance score $36,538 \%$, educational factor with variance score $21,209 \%$, interest factor with variance score $14,097 \%$, life values factor with variance score $7,981 \%$, characters factor with variance score $6,909 \%$, peer socialization factor with variance score $5,805 \%$, society factor with variance score $4,751 \%$, and cognitive factor with variance score $2,710 \%$. Physical factor becomes the most dominant factor since it has varimax rotation score $36,538 \%$, meaning that the total varimax rotation score of physical factor is able to explain the readiness of being teacher in $36,538 \%$.
\end{abstract}

Keywords: Readiness of Being Teacher, College Students 


\section{PENDAHULUAN}

Guru merupakan seseorang yang memegang peranan penting dalam proses pembelajaran di dalam dunia pendidikan. Selain itu guru juga merupakan komponen yang paling berpengaruh terhadap terciptanya proses dan hasil pendidikan yang berkualitas. Menurut Undang-Undang No. 14 Tahun 2005, guru ialah seorang pendidik profesional dengan tugas utamanya mendidik, mengajar, membimbing, mengarahkan, melatih, menilai, dan mengevaluasi peserta didik ada pendidikan anak usia dini melalui jalur formal pendidikan dasar dan pendidikan menengah. Kualitas guru dapat dilihat dari kompetensi yang dimilikinya dan memiliki kesiapan serta berdedikasi penuh terhadap profesinya.

Berdasarkan Peraturan Mentri Pendidikan Nasional Republik Indonesia Nomor 16 Tahun 2007 tentang standar kualifikasi kompetensi guru, ada empat kompetensi yang harus dimiliki seorang guru yaitu, kompetensi pedagogik, kompetensi kepribadian, kompetensi sosial, dan kompetensi profesional. Kompetensikompetensi tersebut dipelajari mahasiswa ketika belajar di perguruan tinggi. Menurut Hamalik (2002:39) "guru akan mampu melaksanakan tanggung jawabnya apabila dia memiliki kompetensi yang diperlukan untuk itu". Untuk menjadi seorang guru yang memiliki kompetensi dan memiliki kesiapan untuk menjadi seorang guru, seseorang dapat menempuh pendidikan di perguruan tinggi yang menyelenggarakan pendidikan keguruan.

Universitas Pendidikan Ganesha (Undiksha) merupakan salah satu perguruan tinggi negeri di Bali yang menghasilkan sarjana pendidikan dan non pendidikan. Salah satu jurusan yang menghasilkan sarjana pendidikan di Universitas Pendidikan Ganesha adalah Jurusan Pendidikan Ekonomi. Dalam Kurikulum Jurusan Pendidikan Ekonomi Tahun 2014, mahasiswa yang menempuh pendidikan di Jurusan Pendidikan Ekonomi akan menempuh kompetensi sasaran kurikulum program S1 yang di kembangkan di Undiksha disusun berdasarkan kompetensi yang terdiri atas kompetensi pedagogik, kompetensi profesional, kompetensi kepribadian, dan kompetensi sosial. Berdasarkan kompetensi tersebut, maka dikembangkan pengelompokan rumpun mata kuliah yang harus ditempuh mahasiswa di Jurusan Pendidikan Ekonomi.

Ke empat kelompok mata kuliah yang tercantum dalam Kurikulum Jurusan Pendidikan Ekonomi Tahun 2014 yaitu, Mata Kuliah Umum (MKU), Mata Kuliah Dasar Kependidikan (MKDK), Mata Kuliah Bidang Keahlian (MKBK), dan Mata Kuliah Keterampilan Proses Pembelajaran (MKKPP) secara umum bertujuan membekali mahasiswa memiliki kompetensi pedagogik, personal, sosial, dan professional. Hal ini diharapkan setelah lulus dalam seluruh mata kuliah yang ada dalam kurikulum Jurusan Pendidikan Ekonomi mahasiswa memiliki kesiapan untuk menjadi guru. Kesiapan seseorang menjadi guru akan tercermin ketika ia mengajar di depan kelas dan dapat dilihat dari kemampuan mahasiswa dalam melaksanakan tugas-tugas keguruan dan pemahaman serta pelaksanaan terhadap kompetensi yang harus dimiliki seorang guru.

Berdasarkan hasil wawancara yang dilakukan kepada seluruh mahasiswa Jurusan Pendidikan Ekonomi angkatan 2014 yang berjumlah 86 mahasiswa yang mengikuti Program Pengalaman Lapangan (PPL 2) dan menanyakan tentang masalah apa yang dihadapi mahasiswa saat melakukan proses pembelajaran dan kesiapan mereka menjadi seorang guru dalam menghadapi siswa di kelas.

Masalah yang di hadapi diantaranya persiapan mengajar kurang, kurang lancar berkomunikasi, kurang menguasai materi, kesulitan dalam mengelola pembelajaran dilihat dari keterampilan pengelolaan kelas karena masih banyak mahasiswa di Jurusan Pendidikan Ekonomi mengeluh soal keributan siswanya di kelas pada saat proses pembelajaran berlangsung. Selain itu masih banyak juga mahasiswa yang mengaku belum menguasai empat kompetensi guru bahkan ada yang kurang paham mengenai empat kompetensi guru. Mahasiswa jurusan Pendidikan Ekonomi angkatan 2014 yang melaksanakan PPL 2

(Program Pengalaman Lapangan 2), terdapat banyak masalah mahasiswa dalam 
melaksanakan proses pembelajaran dalam mengelola kelas supaya mencapai tujuan pembelajaran, dan untuk dapat mengajar dengan kompeten serta mengatasi masalah siswa pada proses pembelajaran berlangsung, mahasiswa masih perlu bimbingan dari dosen pembimbing dan guru pamong. Mahasiswa yang melaksanakan PPL hanya mendapat sedikit pengalaman, pengetahuan, dan keterampilan sebagai seorang guru, karena waktu yang singkat dalam pelaksanaan PPL 2. Hal ini di harapkan mahasiswa setelah melaksanakan PPL 2 mahasiswa sebagai calon guru memiliki kemampuan memperagakan kinerja dalam situasi nyata, baik dalam kegiatan mengajar maupun tugas-tugas keguruan lainnya dan memiliki kesiapan untuk menjadi guru sesuai dengan tuntutan standar pendidikan nasional/Lembaga.

Kesiapan merupakan suatu tingkatan perkembangan seseorang yang berawal dari kematangan atau kedewasaan yang menguntungkan untuk mempraktikkan suatu hal tertentu. Menurut Slameto (2010:113) "kesiapan adalah keseluruhan kondisi seseorang atau individu yang membuatnya siap untuk memberi respons/jawaban di dalam cara tertentu terhadap suatu situasi”. Dalam hal ini, yang dimaksud dengan kondisi seseorang mencakup tiga aspek yaitu aspek pertama meliputi kondisi fisik, mental, dan emosional. Aspek yang kedua meliputi kebutuhan, motivasi, dan tujuan, serta yang ketiga yaitu keterampilan, pengetahuan dan pengertian lain yang dipelajari, seperti menempuh pendidikan di perguruan tinggi agar mahasiswa memiliki kesiapan untuk terjun ke dunia kerja menjadi tenaga pendidik atau guru. Selanjutnya, Dalyono (2005:52) menjelaskan bahwa "kesiapan adalah kemampuan yang cukup, baik fisik maupun mental. Kesiapan fisik berarti tenaga yang cukup dan kesehatan yang baik, sementara kesiapan mental berarti memiliki minat dan motivasi yang cukup untuk melakukan kegiatan". Sedangkan Hamalik (2011:94) mengemukakan "kesiapan adalah tingkatan atau keadaan yang harus dicapai dalam proses perkembangan perorangan pada tingkatan pertumbuhan mental, fisik, sosial, dan emosional". Kesiapan seseorang dalam menjadi guru ditentukan oleh kemampuan dalam menguasai bidangnya, minat, bakat, keselarasan dengan tujuanyang ingin dicapai dan sikap terhadap bidang profesinya. Tekad, semangat dan lingkungan keluarga juga tidak terlepas dari faktor pendukung kesiapan menjadi guru. Menurut Winkel dan Sri Hastuti (2006:647) "kesiapan kerja disebabkan oleh berbagai faktor yang meliputi faktor internal dan faktor eksternal". Faktor internal adalah faktor yang berasal dari dalam diri mahasiswa meliputi nilai-nilai kehidupan, taraf intelejensi, bakat khusus, minat, sifatsifat, pengetahuan, dan keadaan jasmani. Faktor eksternal adalah faktor yang berasal dari luar diri mahasiswa meliputi masyarakat, keadaan sosial ekonomi negara atau daerah, status sosial ekonomi, pengaruh dari seluruh anggota keluarga, pendidikan sekolah, pergaulan dengan teman sebaya, dan tuntutan yang melekat pada masing-masing jabatan.

Nilai-nilai kehidupan dapat diartikan sebagai suatu yang berharga, berguna, dan bermanfaat bagi manusia. Nilai merupakan pandangan seseorang pada suatu hal yang objektif dan membentuk semacam dunia nilai yang menjadi ukuran tertinggi dari prilaku manusia.

Taraf intelegensi merupakan suatu konsep mengenai kemampuan umum individu dalam menyesuaikan diri dengan lingkungannya. Dalam kemampuan yang umum, terdapat kemampuan-kemampuan spesifik yang meemberikan individu suatu kondisi yang tercapainya pengetahuan, kecakapan, atau keterampilan tertentu setelah melalui suatu latihan.

Bakat khusus (talent) merupakan kemampuan bawaan atau keterampilan berupa potensi khusus dan jika memperoleh kesempatan berkembang dengan baik, akan muncul sebagai kemampuan khusus dalam bidang tertentu sesuai potensinya.

Minat merupakan merupakan suatu rasa lebih suka, rasa ketertarikan, dan keterlibatan pada suatu hal atau aktivitas, tanpa ada yang menyuruh. Misalnya minat terhadap pelajaran, profesi, olahraga, atau hobi. Minat bersifat pribadi (individual), artinya setiap orang bisa saja memiliki minat berbeda dengan orang lain. 
Sifat-sifat merupakan kepribadian seseorang individu bereaksi dengan individu lain atau objek. Sifat-sifat disini dapat diartikan kepribadian individu dalam bereaksi atau memberi tanggapan terhadap suatu individu dan objek atau pekerjaan yang diterima dan ada keiinginan untuk berhasil.

Pengetahuan adalah informasi atau maklumat yang diketahui atau disadari oleh seseorang. Dalam pengertian lain, pengetahuan adalah gejala yang ditemui dan diperoleh manusia melalui pengamatan akal. Pengetahuan merupakan informasi yang telah dikombinasikan dengan pemahaman dan potensi untuk menindaki.

Keadaan jasmani merupakan kemampuan seseorang untuk menunaikan tugasnya sehari-hari dengan gampang, tanpa merasa lelah yang berlebihan, serta masih mempunyai cadangan tenaga untuk menikmati waktu senggangnya. Keadaan jasmani juga dapat diartikan kesanggupan dan kemampuan untuk melakukan kerja atau aktivitas.

Masyarakat adalah sekelompok orang yang membentuk sebuah sistem semi tertutup, di mana sebagian besar interaksi adalah antara individu-individu yang berada dalam kelompok tersebut. Masyarakat berpengaruh dalam kesiapan seseorang karena dalam berinteraksi dengan masyarakat seseorang akan menjadi berubah dengan pengetahuan atau informasi yang diterimanya.

Keadaan sosial ekonomi daerah berpengaruh dengan kesiapan kerja seseorang, karena dalam pekerjaan seseorang pasti akan mempertimbangkan gaji dari pekerjaan tersebut apakah layak atau tidaknya, ditentukan oleh keadaan sosial ekonomi Daerah atau Negara.

Status sosial ekonomi merupakan kedudukan atau posisi seseorang dalam kelompok masyarakat yang ditentukan oleh jenis aktivitas ekonomi, pendidikan serta pendapatan. Status sosial ekonomi menuntut seseorang untuk melakukan pekerjaan lain secara siap atau tidak apabila pekerjaan tersebut tidak memuaskan.

Pengaruh dari anggota keluarga bisa menjadi motivasi bagi seseorang untuk melakukan sesuatu yang diinginkan atau belum memiliki kesiapan untuk melakukan sesuatu tersebut, oleh karena itu dorongan atau pengaruh dari seluruh anggota keluarga memaksa kehendak seseorang untuk siap melakukan sesuatu atau pekerjaan.

Pendidikan sekolah merupakan pendidikan yang secara sengaja dirancang dan dilaksanakan dengan aturan-aturan yang ketat, seperti harus berjenjang dan berkesinambungan sehingga disebut pendidikan formal. Sekolah disini berarti lembaga dengan organisasi yang tersusun rapi dan segala aktifitasnya direncanakan sengaja yang disebut kurikulum untuk menuntut seseorang untuk memiliki kesiapan kerja.

Pergaulan dengan teman sebaya adalah lingkungan kedua setelah keluarga, yang berpegaruh bagi kehidupan individu.terpengaruh tidaknya individu dengan teman sebaya tergantung pada presepsi individu terhadap kelompoknya untuk menentukan keputusan yang di ambil nantinya. Kuatnya pengaruh kelompok teman sebaya juga mengakibatkan melemahnya ikatan individu dengan orang tua, sekolah, norma-norma konvensional mengenai kesiapan individu dalam memilih pekerjaan.

Tuntutan yang melekat pada masingmasing jabatan dalam hal kesiapan seseorang untuk menjadi guru adalah tuntutan yang melekat pada diri individu setelah tamat dari pendidikan tinggi akan dituntut untuk menjadi guru atau profesi yang sesuai dengan jurusan serta kurikulum lembaga.

Kesiapan seseorang dalam menjadi guru ditentukan oleh kemampuan dalam menguasai bidangnya, minat, bakat, keselarasan dengan tujuanyang ingin dicapai dan sikap terhadap bidang profesinya. Tekad, semangat dan lingkungan keluarga juga tidak terlepas dari faktor pendukung kesiapan menjadi guru.

Berdasarkan latar belakang masalah yang sudah dikemukakan sebelumnya maka peneliti tertarik untuk meneliti faktorfaktor yang Mempengaruhi Kesiapan Menjadi Guru pada Mahasiswa di Jurusan Pendidikan Ekonomi Angkatan 2014 Undiksha. 


\section{METODE}

Rancangan penelitian yang digunakan dalam penelitian ini adalah jenis rancangan penelitian faktorial. Menurut Sugiyono (2008) analisis faktor adalah suatu teknik yang digunakan untuk menganalisis tentang saling ketergantungan (interindependence) dari beberapa variabel secara simultan menjadi sejumlah faktor yang lebih sedikit dari variabel yang diteliti. Penelitian ini dilakukan di Jurusan Pendidikan Ekonomi, Fakultas Ekonomi, Universitas Pendidikan Ganesha yang terletak di Jalan Udayana No. 11 Singaraja.

Populasi dalam penelitian ini adalah seluruh mahasiswa di Jurusan Pendidikan Ekonomi angkatan 2014 Universitas Pendidikan Ganesha. Sampel dalam penelitian ini berjumlah 86 mahasiswa aktif yang telah lulus Program Pengalaman Lapangan (PPL) yang terbagi menjadi 3 kelas. Menurut Suharsimi Arikunto (2006:130) menyatakan bahwa "populasi adalah keseluruhan subyek yang digunakan untuk penelitian". Dari populasi penelitian diperoleh jumlah sampel yang diambil sebanyak 40 atau sebagian mahasiswa angkatan 2014 yang telah lulus mata kuliah Program Pengalaman Lapangan (PPL) karena terdapat mahasiswa yang tidak mempunyai hasil taraf intelegensi atau hasil tes IQ. Menurut Suharsimi Arikunto (2006:131) "sampel adalah sebagian atau wakil populasi yang diteliti".

Jenis data dalam penelitian ini adalah data kualitatif yang merupakan data yang dinyatakan dalam bentuk kata-kata melalui kuisioner mengenai faktor-faktor yang mempengaruhi kesiapan menjadi guru pada mahasiswa di Jurusan Pendidikan Ekonomi angkatan $2014 \quad$ Universitas Pendidikan Ganesha. Sumber data yang digunakan dalam penelitian ini adalah data primer dan data sekunder. Data primer dalam penelitian ini berupa faktor-faktor yang mempengaruhi kesiapan menjadi guru pada mahasiswa di Jurusan Pendidikan Ekonomi angkatan 2014 Universitas Pendidikan Ganesha. Data sekunder dalam penelitian ini berupa data yang diperoleh dari dokumen atau catatan pihak dari tata usaha Fakultas Ekonomi mengenai jumlah mahasiswa Jurusan Pendidikan Ekonomi angkatan 2014 Undiksha.
Metode pengumpulan data yang digunakan dalam penelitian ini yaitu metode angket atau kuisioner dan metode dokumentasi. Kuisioner (angket) merupakan metode pengumpulan data yang dilakukan dengan memberikan daftar pertanyaan kepada responden untuk dijawab. Metode ini digunakan untuk mengumpulkan data meengenai faktor-faktor yang mempengaruhi kesiapan mahasiswa menjadi guru di Jurusan Pendidikan Ekonomi angkatan 2014 Universias Pendidikan Ganesha. Skala pengukuran yang digunakan dalam penelitian ini adalah skala likert. Skala likert merupakan skala yang mengukur sikap, pendapat dan persepsi seseorang maupun sekelompok orang terhadap fenomena yang terjadi di lapangan Sugiyono (2009). Adapun 5 alternatif jawaban yang memiliki skor penilaian, jika jawaban Sangat Setuju (SS) di beri skor 5, jika jawaban Setuju (S) di beri skor 4, jika jawaban Kurang Setuju (KS) di beri skor, jika jawaban Tidak Setuju (TS) di beri skor 2, dan jika jawaban Sangat Tidak Setuju (STS) di beri skor 1.

Instrumen penelitian yang menggunakan skala likert dapat dibuat dalam bentuk checklist atau pilihan ganda. Sebelum digunakan untuk memperoleh data di lapangan, terlebih dahulu harus diuji tingkat validitas dan reliabelitasnya.

Uji validitas digunakan untuk menguji seberapa baik instrument penelitian mengukur konsep yang seharusnya diukur. Menurut Sugiyono (2011) pengujian validitas dapat dilakukan dengan menggunakan korelasi product moment. Uji validitas dalam penelitian ini dilakukan dengan menggunakan program SPSS versi 16.0 for windows. Jika nilai $r<0,361$ maka dinyatakan tidak valid dan jika $r>0,361$ maka dianggap memenuhi syarat (valid). Uji validitas dalam penelitian ini dilakukan dengan menggunakan program SPSS 16.0 for windows. Uji reliabelitas menunjukkan sejauh mana instrument dapat memberikan hasil pengukuran yang konsisten apabila pengukuran dilakukan secara berulangulang. Nilai batas yang diperkenalkan untuk menilai atau menguji apakah setiap variabel dapat dipercaya, handal dan akurat dipergunakan formula Koefisien Alpha dari Cronbach. Variabel dapat dinyatakan 
reliabel apabila Koefisien Alpha Cronbach $\geq$ 0,6 . Uji reliabilitas dalam penelitian ini dilakukan dengan menggunakan program SPSS versi 16.0 for windows.

Sesuai dengan perumusan masalah, tujuan penelitian, dan jenis data yang dikumpulkan maka analisis data yang digunakan dalam penelitian ini adalah analisis faktor. Menurut Supranto (2010:113) "analisis faktor adalah serangkaian prosedur yang digunakan untuk mengurangi dan meringkat data tanpa kehilangan informasi penting atau mereduksi data dari variabel yang jumlahnya lebih sedikit." Analisis faktor digunakan untuk mengetahui faktor-faktor yang mempengaruhi kesiapan menjadi guru, dengan menggunakan software SPSS.

Prosedur yang digunakan dalam analisis faktor ini yaitu, pertama adalah menghitung matrik korelasi yang bertujuan untuk menguji ketetapan model analisis faktor, maka dapat digunakan Bartlett's test of sphericity yang dipakai untuk menguji bahwa variabel-variabel dalam sampel berkorelasi. Hasil Bartlett's test of sphericity menunjukkan apakah hubungan antara variabel-variabel signifikan atau tidak. Statistik lain yang berguna adalah pengukuran kelayakan sampel Kaiser Meyer Olkin (KMO). Analisis faktor dianggap layak jika besaran KMO nilainya minimal 0,50 . Besaran ini digunakan untuk mengukur derajat korelasi antar variabel dengan kriteria Measure of Sampling Adequacy (MSA) $\geq 0,50$.

Langkah kedua di dalam analisis faktor adalah penentuan jumlah faktor, penentuan jumlah faktor yang ditentukan untuk mewakili variabel-variabel yang akan dianalisis didasarkan pada besarnya eigenvalue serta persentase total variannya. Faktor yang memiliki eigenvalue sama atau lebih besar dari satu yang dipertahankan dalam model analisis faktor, sedangkan yang lainnya dikeluarkan dari model.

Langkah ketiga adalah rotasi faktor (rotation). Hasil dari ekstrasi faktor dalam matrik faktor mengidentifikasi hubungan antar faktor dan variabel individual, namun dalam faktor-faktor tersebut banyak variabel yang berkorelasi sehingga sulit untuk di interprestasikan. Tujuan dilakukannya rotasi faktor ini adalah agar dapat memperoleh struktur faktor yang lebih sederhana sehingga mudah di interprestasikan. Rotasi faktor ini menggunakan metode varimax method. Langkah selanjutnya adalah Interprestasi faktor dengan mengelompokan variabel yang mempunyai faktor loading tertinggi ke dalam faktor tersebut. Untuk menginterprestasikan hasil penelitian ini, faktor loading minimal 0,5 . Variabel yang mempunyai faktor loading kurang dari 0,5 dikeluarkan dari model.

Langkah terakhir dalam analisis faktor adalah mengetahui ketepatan dalam memilih teknik analisis faktor antara Principal Component Analysis (PCA) dengan melihat jumlah residual (perbedaan) antara korelasi yang diamati dengan korelasi yang diproduksi.

\section{HASIL DAN PEMBAHASAN Hasil}

Analisis faktor digunakan untuk menganalisis hipotesis pertama penelitian dengan memasukkan semua total nilai dari masing-masing dimensi-dimensi yang ada pada faktor-faktor tersebut terhadap total skor item. Skor dari masing-masing faktor yang telah terjabar ke dalam dimensidimensi terlebih dahulu ditransformasikan ke dalam data interval, kemudian dilakukan langkah-langkah dalam analisis faktor yaitu, membuat matrik korelasi, penentuan jumlah faktor, rotasi faktor, interpretasi faktor, dan model fit (ketepatan model).

Selanjutnya dalam analisis faktor menguji matriks korelasi menggunakan Barlett's test of Sphericity dengan koefisien Keiser-Meyer-Olkin (KMO) > 0,5 dengan signifikan < 0,05, menentukan banyaknya faktor dengan memilih faktor atau komponen utama yang memiliki parameter akar karakteristik terkecil (eigenvalue) > 1, dan menentukan faktor yang paling mendominasi menggunakan parameter koefisien varimax mendekati +1 dan -1 . Langkah pertama yang dilakukan yaitu dengan menganalisis jawaban responden terhadap angket yang telah dibagikan. Analisis faktor pada penelitian ini dilakukan dalam 3 tahap, sebab ada beberapa faktor yang harus dikeluarkan sampai memenuhi syarat analisis faktor yaitu memiliki nilai > 0,5 . 
Hasil analisis tahap pertama KeiserMeyer-Olkin (KMO) Measure of Sampling Adequacy (MSA) yang bertujuan untuk menguji derajat interkorelasi antara variabel dan ketepatan pemakaian analisis faktor, serta untuk mengetahui kecukupan sampel atau pengukuran kelayakan sampel pada analisis faktor dengan syarat jika nilai KMO $>0,5$ dan uji Bartlett's Test of Sphericity apabila nilai signifikan $<0,05$ Adapun hasil uji KMO dan Bartlett's Test of Sphericity sebesar 0,564 > 0,5 dengan signifikansi sebesar $0,000<0,05$, maka variable dan data dapat terus dianalisis lebih lanjut.

Pada tabel Anti-Image Matrics, terlihat tampak ada 4 faktor yaitu X2 memiliki nilai $0,335<0,5$, X3 memiliki nilai 0,486 < 0,5, X10 memiliki nilai $0,273<0,5$, dan X14 dengan nilai $0,497<0,5$ sehingga faktorfaktor tersebut harus dikeluarkan pada analisis tahap berikutnya.

Dari analisis tahap 1 terlihat communalities, dimana tampak bahwa ada 2 faktor yaitu X3 memiliki nilai 0,446 $<0,05$ dan $\mathrm{X} 14$ dengan nilai $0,476<0,5$ sehingga faktor-faktor tersebut harus dikeluarkan pada analisis tahap berikutnya.

Pada analisis tahap 1 ini, dari Rotated Component Matrix tampak bahwa ada 2 faktor yaitu X9 dan X2 dengan nilai $<0,5$ sehingga harus dikeluarkan pada tahap analisis berikutnya.

Berdasarkan analisis tahap 1 ini tampak bahwa ada 5 faktor yang harus dikeluarkan, yaitu faktor Taraf Intelegensi (X2), Bakat Khusus (X3), Keadaan Sosial Ekonomi Negara atau daerah (X9), Status sosial ekonomi (X10), dan Tuntutan yang melekat pada masing-masing jabatan (X14). Oleh karena itu perlu dilakukan analisis kembali tanpa memakai kelima faktor tersebut.

Pada analisis tahap 2, terjadi perubahan angka Keiser-Meyer-Olkin (KMO) Measure of Sampling Adequacy (MSA) sebesar 0,682 > 0,5 dengan signifikansi sebesar $0,000<0,5$, maka variable dan data dapat terus dianalisis lebih lanjut.Tabel Anti-Image Matrices menunjukkan bahwa data memiliki nilai yang baik karena semua faktor $>0,5$ sehingga data dikatakan cukup baik serta dapat diteruskan pada analisis lebih lanjut.

Communalities pada analisis tahap 2 tampak bahwa ada 1 faktor yaitu X11 memiliki nilai $0,484<0,5$ sehingga faktor tersebut harus dikeluarkan dan tidak dipakai pada analisis tahap berikutnya.

Pada analisis tahap 2 ini, dari Rotated Component Matrix diperoleh 3 faktor yang nanti akan membentuk variabel-variabel kesiapan menjadi guru pada mahasiswa Pendidikan Ekonomi angkatan 2014 Universitas Pendidikan Ganesha.

Berdasarkan analisis tahap 2 ini tampak bahwa ada 1 faktor yang harus dikeluarkan, yaitu faktor Pengaruh seluruh anggota keluarga (X11). Oleh karena itu perlu dilakukan analisis kembali tanpa memakai faktor X11.

Tabel 1. Hasil uji KMO and Bartlett's Test of Sphericity

\begin{tabular}{llr}
\hline Kaiser-Meyer-Olkin Measure of Sampling Adequacy. & .681 \\
\hline Bartlett's Test of Sphericity & Approx. Chi-Square & 91.701 \\
& Df & 28 \\
& Sig. & .000
\end{tabular}

Pada tabel 1, analisis tahap 3 terjadi perubahan angka lagi pada Keiser-MeyerOlkin (KMO) Measure of Sampling Adequacy (MSA) sebesar 0,681 > 0,5 dengan signifikansi $0,000<0,05$, maka variabel dan data dapat terus dianalisis lebih lanjut.
Pada tabel Anti-Image Matrices menunjukan bahwa data memiliki nilai yang baik karena semua faktor $>0,5$ sehingga data dikatakan cukup baik serta dapat diteruskan pada analisis lebih lanjut. 
Tabel 2. Hasil Analisis Communalities

\begin{tabular}{lcl}
\hline \multicolumn{1}{c}{ Faktor } & Nilai Extraction & Keputusan \\
\hline Nilai-nilai Kehidupan $\left(\mathrm{X}_{1}\right)$ & $0,758>0,50$ & Dapat digunakan untuk analisis faktor \\
Minat $\left(\mathrm{X}_{4}\right)$ & $0,613>0,50$ & Dapat digunakan untuk analisis faktor \\
Sifat-sifat $\left(\mathrm{X}_{5}\right)$ & $0,670>0,50$ & Dapat digunakan untuk analisis faktor \\
Pengetahuan $\left(\mathrm{X}_{6}\right)$ & $0,738>0,50$ & Dapat digunakan untuk analisis faktor \\
Keadaan Jasmani $\left(\mathrm{X}_{7}\right)$ & $0,836>0,50$ & Dapat digunakan untuk analisis faktor \\
Masyarakat $\left(\mathrm{X}_{8}\right)$ & $0,814>0,50$ & Dapat digunakan untuk analisis faktor \\
Pendidikan Sekolah $\left(\mathrm{X}_{12}\right)$ & $0,634>0,50$ & Dapat digunakan untuk analisis faktor \\
Pergaulan Teman Sebaya $\left(\mathrm{X}_{13}\right)$ & $0,683>0,50$ & Dapat digunakan untuk analisis faktor \\
\hline
\end{tabular}

Pada Tabel 2, Communalities pada analisis tahap 3 tampak bahwa semua faktor bernilai $>0,50$ sehingga dapat dikatakan bahwa faktor-faktor tersebut cukup efektif.

Pada Total Variance Explained (TVE) diketahui bahwa nilai eigenvalue yang $>1$ berubah menjadi 3 faktor yang akan dibentuk oleh faktor-faktor yang akan dimasukkan ke dalam model untuk membentuk variabel yang baru.

Pada table 3, analisis tahap 3 ini, dari Rotated Component Matrix diperoleh 3 faktor yang nanti akan membentuk variabelvariabel kesiapan menjadi guru pada mahasiswa Pendidikan Ekonomi angkatan 2014 Universitas Pendidikan Ganesha.

Tabel 3. Analisis Rotated Component Matrix

\begin{tabular}{lccc}
\hline & \multicolumn{3}{c}{ Component } \\
\cline { 2 - 4 } & 1 & 2 & 3 \\
\hline Keadaan Jasmani $\left(\mathrm{X}_{7}\right)$ & .901 & -.004 & -.158 \\
Pendidikan Sekolah $\left(\mathrm{X}_{12}\right)$ & .796 & .011 & .033 \\
Minat $\left(\mathrm{X}_{4}\right)$ & .709 & .062 & .326 \\
Nilai-nilai Kehidupan $\left(\mathrm{X}_{1}\right)$ & .691 & .438 & .299 \\
Sifat-sifat $\left(\mathrm{X}_{5}\right)$ & .001 & .816 & .067 \\
Pergaulan Teman Sebaya $\left(\mathrm{X}_{13}\right)$ & .156 & .811 & -.026 \\
Masyarakat $\left(\mathrm{X}_{8}\right)$ & .181 & -.099 & .878 \\
Pengetahuan $\left(\mathrm{X}_{6}\right)$ & -.077 & .530 & .672 \\
\hline
\end{tabular}

Menurut Slameto (2010:113), "kesiapan adalah keseluruhan kondisi seseorang yang membuatnya siap untuk memberi respon/jawaban dengan cara tertentu terhadap suatu situasi. Kondisi tersebut mencakup 3 aspek, yaitu pertama kondisi fisik, mental, dan emosional, kedua kebutuhan, motivasi, dan tujuan, dan ketiga pengetahuan dan pengertian.

Hasil dari analisis faktor terbentuk 3 aspek kondisi yang mempengaruhi kesiapan menjadi guru pada mahasiswa Pendidikan Ekonomi angkatan 2014
Universitas Pendidikan Ganesha yang dapat dilihat pada tabel 4.

Sedangkan pengujian hipotesis penelitian, untuk menentukan dimensi atau faktor yang paling dominan mempengaruhi kesiapan menjadi guru pada mahasiswa Pendidikan Ekonomi angkatan 2014 Undiksha, digunakan parameter koefisien varimax mendekati +1 dan -1 . Secara lebih rinci hasil ringkasan rotasi dari matrik faktor memuat nilai varimax rotation, dapat dilihat pada tabel 
Tabel 4. Hasil Analisis Faktor

\begin{tabular}{|c|c|c|c|}
\hline No & Indikator & $\begin{array}{l}\text { Muatan } \\
\text { Faktor }\end{array}$ & Aspek/Variabel \\
\hline 1 & Keadaan Jasmani $\left(\mathrm{X}_{7}\right)$ & 0,901 & \\
\hline 2 & Pendidikan Sekolah ( $\left.\mathrm{X}_{12}\right)$ & 0,796 & Kondisi fisik, Mental, \\
\hline 3 & Minat $\left(X_{4}\right)$ & 0,709 & dan emosional \\
\hline 4 & Nilai-nilai Kehidupan $\left(\mathrm{X}_{1}\right)$ & 0,691 & \\
\hline 5 & Sifat-sifat $\left(X_{5}\right)$ & 0,816 & Kebutuhan, Motivasi, \\
\hline 6 & Pergaulan Teman sebaya $\left(\mathrm{X}_{13}\right)$ & 0,811 & dan Tujuan \\
\hline 7 & Masyarakat $\left(\mathrm{X}_{8}\right)$ & 0,878 & Pengetahuan dan \\
\hline 8 & Pengetahuan $\left(\mathrm{X}_{6}\right)$ & 0,672 & Pengertian \\
\hline
\end{tabular}

Tabel 5. Matriks Rotasi Hasil Analisis Faktor

\begin{tabular}{lccccc}
\hline \multicolumn{1}{c}{$\begin{array}{c}\text { Dimensi atau faktor kesiapan } \\
\text { menjaaı guru }\end{array}$} & Variance & & \multicolumn{3}{c}{ Varimax rotation } \\
& & $(\%)$ & $(1)$ & $(2)$ & $(3)$ \\
\cline { 4 - 6 } & & 36,538 & 0,901 & $-0,004$ & $-0,158$ \\
Keadaan Jasmani & & 21,209 & 0,796 & 0,011 & 0,033 \\
Pendidikan Sekolah & & 14,097 & 0,709 & 0,062 & 0,326 \\
\cline { 5 - 7 } & & &
\end{tabular}

Berdasarkan tabel 5 diatas, dapat diketahui bahwa faktor yang paling dominan yang mempengaruhi kesiapan menjadi guru pada mahasiswa Pendidikan Ekonomi angkatan 2014 Universitas Pendidikan Ganesha adalah faktor Keadaan Jasmani dengan nilai varimax rotation 0,901 mendekati +1 dan -0,158 mendekati -1 dengan variance sebesar $36,538 \%$. Artinya kejelasan dari dimensi atau faktor kesiapan menjadi guru pada mahasiswa Pendidikan Ekonomi angkatan 2014 Universitas Pendidikan Ganesha yang paling mendominasi sebesar $36,538 \%$.

\section{Pembahasan}

Berdasarkan penelitian dapat diketahui bahwa faktor yang mempengaruhi kesiapan menjadi guru pada mahasiswa Pendidikan Ekonomi angkatan 2014 Universitas Pendidikan Ganesha adalah faktor intern dan faktor ekstern. Faktor intern merupakan faktor yang bersumber dari dalam diri mahasiswa, meliputi nilainilai kehidupan, taraf intelegensi, bakat khusus, minat, sifat-sifat, pengetahuan, dan keadaan jasmani. Sedangkan faktor ekstern merupakan faktor yang bersumber dari luar

diri mahasiswa, meliputi faktor masyarakat, keadaan sosial ekonomi Negara atau daerah, status sosial ekonomi, pengaruh seluruh anggota keluarga, pendidikan sekolah, pergaulan teman sebaya, dan tuntutan masing-masing jabatan (Winkel, 2006). Dalam hasil penelitian ini dapat diketahui faktor yang mempengaruhi kesiapan menjadi guru pada mahasiswa Pendidikan Ekonomi angkatan 2014 Universitas Pendidikan Ganesha digolongkan menjadi 3 variabel/aspek yang sesuai dengan pendapat Slameto (2010), kesiapaan merupakan keseluruhan kondisi seseorang yang membuatnya siap untuk memberi respon/jawaban dengan cara tertentu terhadap suatu situasi. Kondisi tersebut mencakup 3 aspek, yaitu pertama kondisi fisik, mental, dan emosional yang terdiri dari faktor keadaan jasmani, pendidikan sekolah, minat, dan nilai-nilai kehdiupan. Kedua kebutuhan, motivasi, dan tujuan yang terdiri dari faktor sifat-sifat dan pergaulan teman sebaya. Ketiga keterampilan, pengetahuan dan pengertian yang telah dipelajari terdiri dari faktor masyarakat dan pengetahuan. 
Berdasarkan pengujian hipotesis konseptual untuk menentukan faktor kesiapan menjadi guru belajar parameter varimax rotation dari dimensi atau faktor yang mempengaruhi kesiapan menjadi guru pada mahasiswa Pendidikan Ekonomi angkatan 2014 Universitas Pendidikan Ganesha yang paling mendekati +1 atau mendekati - 1. Dari hasil rotasi terhadap faktor matriks pada varimax rotation, maka faktor yang paling mendominasi pada kedua komponen utama yang terbentuk yaitu, faktor keadaan jasmani dengan nilai variance explained sebesar $36,538 \%$, faktor pendidikan sekolah dengan nilai variance explained sebesar $21,209 \%$, dan faktor minat dengan nilai variance explained sebesar 14,097\%. Sehingga dapat disimpulkan bahwa faktor yang mendominasi kesiapan menjadi guru pada mahasiswa jurusan Pendidikan Ekonomi angkatan 2014 Universitas Pendidikan Ganesha adalah faktor keadaan jasmani, pendidikan sekolah , dan minat.

Faktor keadaan jasmani, pendidikan sekolah, dan minat merupakan faktor yang dominan mempengaruhi kesiapan menjadi guru pada mahasiswa Pendidikan Ekonomi angkatan 2014 Universitas Pendidikan Ganesha. Faktor ini paing dominan dari pada faktor-faktor yang lainnya, keadaan jasmani merupakan kemampuan seseorang untuk menunaikan tugasnya sehari-hari dengan gampang, tanpa merasa lelah yang berlebihan, serta masih mempunyai cadangan tenaga untuk menikmati waktu senggang. Keadaan jasmani dapat juga diartikan kesanggupan dan kemampuan untuk melakukan aktivitas yang berhubungan dengan kondisi fisik mahasiswa dalam menjadi guru dan kesanggupan mahasiswa untuk siap menjadi guru. Pendidikan sekolah merupaka lembaga dengan organisasi yang tersusun rapi dan segala aktifitas direncanakan dengan kurikulum untuk menuntut seseorang memiliki kesiapan kerja mahasiswa sesuai dengan bidang pendidikan mahasiswa jurusan Pendidikan Ekonomi setelah lulus dari Universitas Pendidikan Ganesha maka mahasiswa siap untuk menjadi guru. Begitu pula dengan minat yang sama halnya dengan kecerdasan dan motivasi, karena memberi pengaruh terhadap kesiapan mahasiswa dalam menjadi guru. Minat merupakan rasa lebih suka, rasa ketertarikan, dan keterlibatan pada suatu hal atau aktifitas, tanpa ada yang menyuruh maka secara langsung akan siap untuk melakukan hal apapun termasuk menjadi guru.

\section{SIMPULAN DAN SARAN Simpulan}

Berdasarkan hasil penelitian dan pembahasan pada bagian sebelumnya, maka dapat diambil simpulan yaitu, hasil analisis faktor dari 14 indikator mereduksi 8 yang mengelompok menjadi 3 aspek atau variabel yang mempengaruhi kesiapan menjadi guru pada mahasiswa jurusan Pendidikan Ekonomi angkatan 2014 Universitas Pendidikan Ganesha, masingmasing pengaruh 11 indikator terhadap kesiapan menjadi guru, faktor keadaan jasmani memiliki eigenvalue sebesar 2,923 dengan nilai variance sebesar $36,536 \%$, faktor pendidikan sekolah memiliki eigenvalue sebesar 1,697 dengan variance sebesar $21,209 \%$, faktor minat memiliki eigenvalue sebesar 1,128 dengan variance sebesar 14,097\%, faktor nilai-nilai kehidupan memiliki eigenvalue sebesar 0,638 dengan variance sebesar 7,981\%, faktor sifat-sifat memiliki eigenvalue sebesar 0,553 dengan variance sebesar $6,909 \%$, faktor pergaulan teman sebaya memiliki eigenvalue sebesar 0,464 dengan variance sebesar 5,805\%, faktor masyarakat memiliki eigenvalue sebesar 0,380 dengan variance sebesar $4,751 \%$, dan faktor pengetahuan memiliki eigenvalue sebesar 0,217 dengan variance sebesar $2,710 \%$. Faktor yang paling dominan mempengaruhi kesiapan menjadi guru pada mahasiswa jurusan Pendidikaan Ekonomi angkatan 2014 Universitas Pendidikan Ganesha adalah faktor keadaan jasmani dengan nilai varimax rotation sebesar $36,536 \%$.

\section{Saran}

Berdasarkan simpulan diatas, maka saran yang dapat diajukan dalam penelitian ini, adalah pihak lembaga atau jurusan faktor-faktor yang mempengaruhi kesiapan menjadi guru pada mahasiswa jurusan Pendidikan Ekonomi Undiksha, sehingga 
jurusan bisa membimbing mahasiswa supaya siap untuk menjadi guru bagi peserta didik. Selain itu jurusan bisa melatih keadaan fisik, mental, dan emosional mahasiswa dalam menghadapi peserta didik, serta memotivasi dan pengetahuan dalam melakukan proses pembelajaran atau membimbing peserta didik karena aspek tersebut bisa mempersiapkan mahasiswa untuk dapat menjadi guru yang berkompeten, otomatis keadaan jasmani mahasiswa akan terlatih karena memiliki kesanggupan untuk menjadi guru bagi peserta didik yang merupakan faktor paling dominan mempengaruhi kesiapan menjadi guru pada mahasiswa jurusan Pendidikan Ekonomi angkatan 2014 Universitas Pendidikan Ganesha adalah faktor keadaan jasmani yang meliputi kondisi kesehatan mahasiswa dan kesanggupan mahasiswa dalam melakukan pekerjaan. Jika kondisi tersebut dimiliki mahasiswa maka mahasiswa akan siap untuk menjadi guru karena kesehatan yang baik dan kesanggupan untuk melakukan pekerjaan maka pihak lembaga maupun jurusan akan mencetak guru yang berkompeten.

Bagi mahasiswa, faktor kesiapan menjadi guru yang besar pengaruhnya dari pada faktor lain ada 3 yaitu keadaan jasmani, pendidikan sekolah, dan minat. Oleh karena itu diharapkan mahasiswa hendak memiliki kesanggupan, kondisi yang baik, motivasi, dan menekuni setiap mata kuliah pendidikan supaya memiliki kesiapan menjadi guru bagi peserta didik.

Selain itu, bagi pihak peneliti selanjutnya penelitian ini dapat dijadikan refrensi dan acuan bagi penelitian berikutnya. Oleh karena itu hendaknya dapat mengembangkan tulisan ini dan menggali informasi yang berhubungan dengan kesiapan menjadi guru sehingga dapat membantu berbagai pihak yang terkait dalam pendidikan atau tugas akhir yang terkait dengan kesiapan menjadi guru.

\section{DAFTAR PUSTAKA}

Arikunto, Suharsimi. 2010. Prosedur Penelitian: Suatu Pendekatan Praktik. Jakarta: PT Rineka Cipta.
Dalyono. 2005. Psikologi Pendidikan. Jakarta: PT Rineka Cipta.

Depdiknas. 2003. Undang-Undang Republik Indonesia No. 20 tahun 2003 tentang Sistem Pendidikan Nasional. Jakarta: Dirjend. Pendidikan Dasar dan Menengah.

2005. Undang-Undang Nomor 14 tentang Guru dan Dosen. Jakarta: Depdiknas.

2007. Peraturan Menteri Pendidikan Nasional tentang Standar Kualifikasi dan Kompetensi Guru. Jakarta: Depdiknas.

Hamalik, Oemar. 2002. Pendidikan Guru Berdasarkan Pendekatan Kompetensi. Jakarta: PT Bumi Aksara.

Sardirman. 2011. Interaksi dan Motivasi Belajar Mengajar. Jakarta: Rajawali Pers.

Slameto. 2010. Belajar dan Faktor-faktor yang Mempengaruhinya. Jakarta: PT Rineka Cipta.

Sugiyono. 2008. Metodelogi Penelitian. Bandung: Alfabeta.

Suliyanto. 2005. Metode Riset Bisnis. Yogyakarta: CV. Andi Offset.

Winkel S.J dan MM. Sri Hastuti. 2006. Bimbingan dan Konseling di Institusi Pendidikan. Yogyakarta : Media Abadi. 